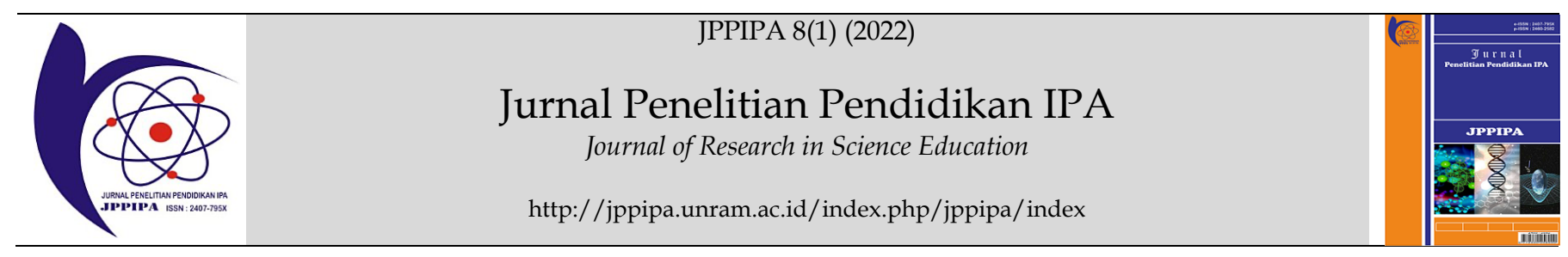

\title{
Development of Social and Culture Aspects Pre-service Science Teachers on Learning for Nature of Science
}

\author{
Euis Nursa' adah ${ }^{*}$, Bhakti Karyadi1 ${ }^{1}$, Ratu Eva Febriani² ${ }^{2}$ Ahmad Mudzakir ${ }^{3}$ \\ ${ }^{1}$ Graduate School of Science Education, University of Bengkulu, Bengkulu, Indonesia \\ ${ }^{2}$ Economic Development Department, University of Bengkulu, Bengkulu, Indonesia \\ ${ }^{3}$ Chemistry Education Department, Indonesia University of Education, Bandung, Indonesia.
}

DOI: $10.29303 /$ jppipa.v8i1.927

\section{Article Info}

Received: August 30, 2021

Revised: January 10, 2022

Accepted: January 13, 2022

Published: January 31, 2022

\begin{abstract}
Understanding aspects of the Nature of Science (NOS) for preservice science teachers is one of the essential components to be able to understand Science and its processes. There are seven aspects of NOS: empirical, inference, creative, latent theory, tentative, scientific procedural myths, theories and laws of science, social and cultural dimensions, and their embedding in science. There are 48 preservice science teachers involved in this study. Researchers explored their views about NOS and Indigenous Knowledge (IK) through a validated questionnaire. Results showed that the students' opinions on NOS consisted of empirical, tentative, inference, law, scientific theory, and creativity. Meanwhile, aspects of laden theory, myths of scientific procedures, and social and cultural dimensions embedded with science have not been described by students. Fortunately, the students presented IK as an authentic context based on the culture in science learning. Students express IK ideas: 1 ) biomedicine (40 students), Biopesticide (2 students), beauty ingredients ( 2 students), additives (1 student), and supernatural medicine (1 student). Integrating Science and IK as an authentic context in science learning leads IK toward high technology and strengthens NOS aspects. In addition, the assumption that IK has no future is declining.
\end{abstract}

Keywords: Social and Culture; Nature of Science; Learning; Ethnoscience.

Citation: $\quad$ Nursa'adah, E., Karyadi, B., Febriani, R. E., \& Mudzakir, A. (2022). Development of Social and Culture Aspects Pre-service Science Teachers on Learning for Nature of Science. Jurnal Penelitian Pendidikan IPA, 8(1), $204-208$. https://doi.org/10.29303/jppipa.v8i1.927

\section{Introduction}

Scientific literacy provides three aspects- nature of science, way Science and society interact, and content of science itself- is expected to equip people as consumers of science. The latter must make intelligent decisions regarding their lives. A literate society not only knows the concepts, hypotheses, and scientific theories in the decision-making process but also have an understanding of aspects of the Nature of Science (NOS) (Bayir, et al., 2013; Bell \& Lederman, 2003; Lederman, et al., 2002)

Scientists define NOS as a way of knowing and the values contained in developing Science (Abd-elkhalick, 2013.). There are seven (7) aspects of NOS, which consist of 1) Empirical, scientific claims are born or consistent from natural observations, 2) inference, 3) creative, scientists need creativity in making models to be easy to understand, 4) laden theory, the way of investigation and interpretation is influenced by many factors, 5) tentative, scientific knowledge is not absolute, 6) myths of scientific procedures, 7) theories and laws of Science, 8) social dimensions of Science, 9) social and culturally embedded in Science (Bayir, et al., 2013; Abd-el-khalick, 2013). A reasonable conception of the NOS aspect is closely related to understanding the concept and the process of accepting the idea (Temel, et al., 2018). In addition, scientists believe that providing aspects of NOS is essential to replace the subjectivity of 
public knowledge and mystical knowledge (Kampourakis, 2016).

Several previous studies have suggested that both teachers and students of Science do not have sophisticated knowledge about NOS; most are in the naïve category (Bayir, et al., 2013). In other hand, analysis of NOS aspects in the NGSS document shows that NGSS contains 92\% NOS aspects, 78\% written implicitly, while Indonesian curriculum documents implicitly do not contain NOS aspects (Mccomas \& Nouri, 2016; Kaya \& Erduran, 2016; S. Kaya, et al, 2018; Olson, 2018).

Regarding these results, researchers can conclude that providing aspects of NOS in science learning is very important. Because Science itself is inseparable from aspects of NOS - empirical, inference, creative, latent theory, tentative, relationship theory and law, and social and cultural integration in Science - then presenting an actual context in science learning is expected to instill the NOS aspect. In this study, the real context is intense to indigenous knowledge (IK).

IK is a unique traditional knowledge related to a region (Aikenhead, 2006). IK often regards nonscientific knowledge; technological development is complex, so people assume there is no future for IK. Also, IK is considered unable to meet the needs of modern society. Therefore, the younger generation prefers to live with modern technology rather than utilizing IK. As a result, many cultures are loose (Rist \& Dahdouh-Guebas, 2006).

Integration of science concepts with IK is intense to connect culture with the idea of Science (Adibe, 2014). The integration results in many terms, such as ethnoscience, ethnobotany, ethnobiology, and many others. Besides, the student uses the science concept to validate the IK to maintain the IK role and sustainability. IK can be supported chiefly by the younger generation and developed to be more valuable and practical through this strengthening.

Many examples of the integration of IK with science concepts in schools include 1) plant medicine with the concept of neutralization, fermentation, reproduction, and human disease, 2) the use of natural materials with the concept of chemicals in the household, 3) clay houses with the concept of conductivity (Chaudhuri, 2016; Baquete, et al., 2016; Said-ador, 2017). The results show that implementation of integration of IK with Science in learning Science has a significant effect on the content and attitudes of student science without gender differences (Ajayi, et al., 2017; Fasasi, 2017; Bullen \& Roberts, 2018).

The integration of IK and science concepts in learning indicate to produce emotional Science because they are directly involved in the actual context so that students' scientific attitudes become well. IK integration in science learning can present a transparent interconnection between social phenomena and culture with the concept of Science. This statement is in line with the opinion of scientists who state that teaching science must be by nature (Nola, 2011; Dagher \& Erduran, 2016; Temel, et al., 2018).

Scientists believe that providing aspects of NOS is essential to replace the subjectivity of public knowledge and mystical knowledge (Kampourakis, 2016). By integrating NOS aspects and IK, students no longer think that the scientific theories they learn are different from the phenomena they encounter in their lives so that learning becomes meaningful and complete.

Regarding the state's background, this study will explore students' conceptions of aspects of NOS and IK as the real context of local culture in science learning for preservice science teachers. In addition to strengthening the NOS aspects and science content, research data provides an opportunity to produce multidisciplinary science learning designs as well as provide an excellent opportunity to develop them into learning base real data and context, building networks of concepts, setting IK module base practices, and creating products innovation towards entrepreneurs for the younger generation.

\section{Method}

This study involved 48 preservice science teachers at the third level of a public university in Bengkulu Province. Students have studied basic science courses such as general chemistry, biology, and physics. In addition, they have also studied courses that provide academic skills. This research has used a survey method design with two main objectives-generate students' conceptions regarding the aspects of NOS and also IK as a real context in science learning. Researchers present seven questionnaires to explore students' views on complexities of science, objective of science, the aim of scientific research, scientific knowledge, scientific theory.

Students' views of NOS were mapped by adjusting NOS aspects- empirical, inference, creative, latent theory, tentative, relationship theory, law, and social and cultural integration in science.

Furthermore, students ask more questions about $\mathrm{IK}$, the actual context in science learning. The IK asked for priority is the Bengkulu community regarding utilization of natural ingredients as medicines, cosmetics, biopesticides, and food security; has been conducted on other local wisdom such as earthquakeresistant houses, community behavior, and natural resource management. 


\section{Result and Discussion}

Regarding the purpose of the research- exploring the conceptions of aspects of NOS preservice science teacher and mapping them and exploring real context related to IK, especially IK Bengkulu as real context in science learning. Based on the purposes, this section divided into two sections. One about view of NOS preservice science teachers and IK as a real context in science learning.

\section{View of NOS Preservice Science Teachers}

Students' views on the aspects of NOS - empirical, inference, creative, latent theory, tentative, relationship theory and law, as well as social and cultural integration in science - were measured through 5 questionnaires.

Students' views on the aspects of NOS are present in Figure 1.

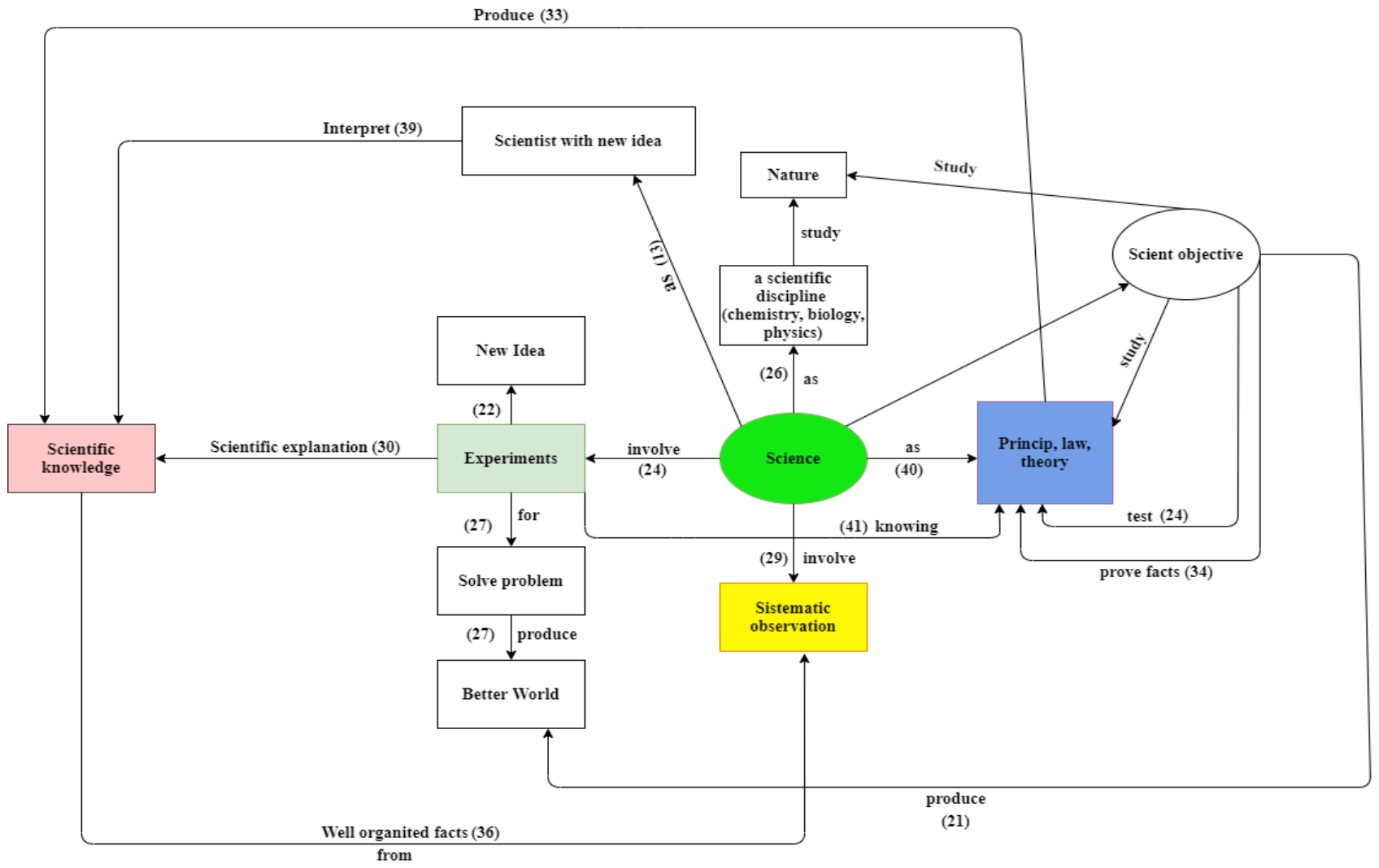

Figure 1. Students' Views on the Aspects of NOS

Figure 1 explains that students describe Science as a discipline such as chemistry, physics, biology (26 students) study laws and theories that explain natural phenomena (40 students). A total of 33 students described Science as knowledge related to the process, where Science is a series of observations and experiments about nature. Through experimentation, a group of people produces new ideas to solve problems and make life better.

Students' views on the purpose of science, 1) explain the phenomenon of natural change (41 students), 2) science as a way to find new ways to make a better world (22 students). Unfortunately, this is contrary to the opinion of students. Most of them think that scientists collect as much data as possible to conclude a law (41 students), although some argue that scientist carries out scientific research to help human life for the better (27 students).
Students' view of current scientific knowledge is based on perspectives, ideas, and interpretations of scientists from the past (39 students). In comparison, 36 students think scientific knowledge is a well-organized collection of facts. This opinion leads to viewing scientific theory as a correct interpretation and explanation that scientists have proved. Unfortunately, some of them think that scientific theories are facts that Science has proved through various experiments.

From all the conceptions of preservice science teachers regarding the NOS aspect, in general, students already have a concept about 1) Empirical, scientific knowledge claims are born from observations of nature, this is shown by their opinion that Science always involves observations and experiments, 2) Tentative, scientific knowledge is not absolute, their opinion shows this that Science always produces new ideas to produce new scientific knowledge, 3) 
inference, students focus on observation and experimentation, they did not notice the difference between observation and inference, 4) theory and the law of Science, students assume that principles, laws, and theories are products of Science they have not been able to distinguish or make connections among the three, 5) Creative, in this aspect it can be seen from the perspective of students who think that scientists are a group of people who always produce a new idea that is constantly being developed by scientist to produce a better life.

Aspects of NOS that students in this study do not emphasize are 1) laden theory, where the background of scientists will influence them to determine the scientific method, 2) myths about scientific procedures, students still think that scientific procedures have been established by scientists, even though there is no specific procedure that leads to valid claims, 3) social and cultural dimensions embedded with Science, this aspect is not yet clearly related, although they agree that Science was born to solve problems.

Sciencetist explain science as natural phenomena; in other words, Science is a body of knowledge about nature, a series of experiments, and continuous interaction between material and social to develop knowledge (Bayir, 2014). This material and social interaction have not been reflected in students' conceptions when describing Science. Meanwhile, Science influences and is influenced by many elements of culture. Therefore, Science and socio-culture will permanently be embedded.

Regarding these findings, aspects of the sociocultural dimensions embedded with science are explored through the IK to strengthen other NOS aspects that students have put forward in Figure 1. In line with research results (Kaya, et al., 2018) argues that this socio-cultural aspect can conceptualize the role of Science in socio-economics and vice versa so that they are mutually reinforcing.

Its implementation in learning will strengthen the practice of NOS in science learning. Research findings indicate that curriculum documents in several countries, including Indonesia have not fully embedded the recommended NOS in learning (Olson, 2018; Mccomas \& Nouri, 2016)

\section{IK as Real Context in Science Learning}

The IK explored is related to the utilization of natural ingredients as medicines, cosmetics, biopesticides, and food security, other local wisdom such as earthquake-resistant houses, community behavior, and natural resource management. IK proposed by preservice science teachers is present in Figure 2.

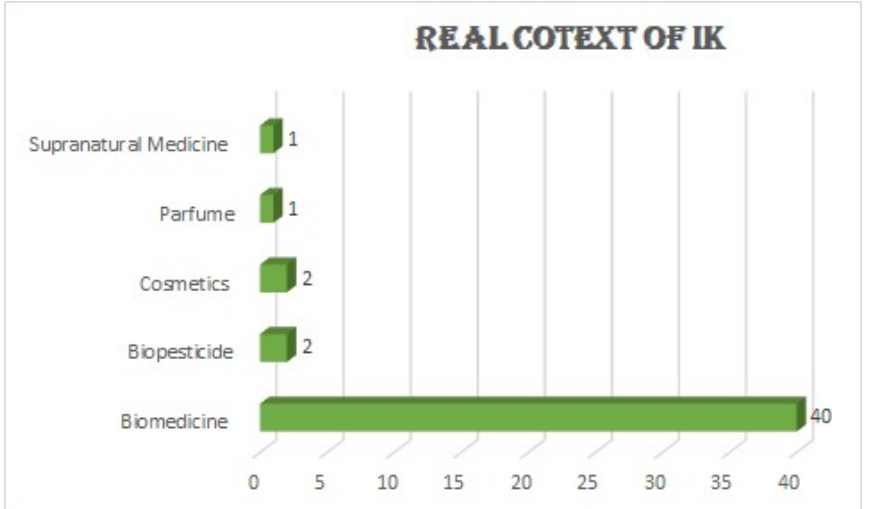

Figure 2. IK as Real Context in Science Learning

Figure 2 explains that the IK proposed by 48 preservice teachers are categorized into biomedicine, Biopesticide, cosmetics, perfume, and supernatural medicine. Biomedicine is the context most frequently suggested by students. Biomedicine utilizes the roots, leaves, and sap of local plants as medicine. Some of them are Jatropha Curcas (Jatropa cina) sap as a wound medicine, Averrhoa bilimbi (Belimbing wuluh) and Coleus amboinicus (Daun bangun-bangun) as antioxidants, Codiaeum variegatum (daun puding) as a medicine for bruises, and others.

There are many types of plants typical of Bengkulu, which were used by the community as medicines. The identification results show that there are 47 species of plants used as medicine. 40 species of 47 contain flavonoids with varying levels, and 11 species contain many flavonoids. Besides, there are 25 species of plants that have the potential as biopesticides through simple processing, which are extracted, soaked, pounded, and placed around the yard (Adfa, 2005; Utami, et al., 2010; Iskandar, 2016). Regarding previous research, it is known that the concept of Science can be used to validate IK so that the sustainability of IK is maintained.

Limitations of the IK stated by the students in this study have not noted the value aspects of the community IK, even though there are several potentials regarding the strengthening of value aspects and environmental management that can integrate into science learning. This is as reported in the identification of IK research carried out on the analysis of local wisdom earthquake-resistant building, behavior, and management of natural resources (Triyadi, et al., 2017; Dihamri, et al., 2016; Wahono, et al., 2016). The results show that modern society can learn from local people who apply certain cultures to survive.

\section{Conclusion}

Student views on the aspects of NOS-empirical, inference, creative, latent theory, tentative, scientific procedural myths, theories and laws of science, social 
and cultural dimensions and their embedding in science, 48 students can describe empirical, tentative, inference, law and scientific theory, and creative. Meanwhile, aspects of laden theory, myths of scientific procedures, and social and cultural dimensions embedded with science have not been described by students.

Students put forward the strengthening of social and cultural aspects as real contexts in science learning through the IK consisting of biomedicine, biopesticides, cosmetics, additives, and supernatural medicine. Many researchers have suggested the integration of science and socio-cultural aspects in science learning strengthen the NOS aspects in formal education.

\section{Acknowledgements}

Thanks and appreciation are given to University of Bengkulu for providing funding through the Unggulan research program. We would like to thank Undergraduate students of science education program university of Bengkulu

\section{References}

Abd-el-khalick, F. (n.d.). Examining the Sources for our Understandings about Science: Enduring conflations and critical issues in research on nature of science in Examining the Sources for our Understandings about Science: Enduring conflations and critical issues in research on . April 2013, 37-41.

Adfa, M. (2005). Survey etnobotani , studi senyawa flavonoid dan uji brine shrimp beberapa tumbuhan obat tradisional suku Serawai di Propinsi Bengkulu. Gradien. 1(1).

Adibe, M. I. (2014). Innovations in science and technology education: A case for ethnoscience based science classrooms. International Journal of Scientific \& Engineering Research, 5(1), 52-56.

Ajayi, O. V., Agamber, T. S., \& Angura, T. M. (2017). Effect of gender on students ' interest in standard mixture separation techniques using ethnochemistry teaching approach. Sky Journal of Educational Research, 5(5), 027-033, Retrieved from: https://papers.ssrn.com/sol3/papers.cfm?abstra ct_id=3066324

Baquete, A. M., Grayson, D., \& Mutimucuio, I. V. (2016). An Exploration of Indigenous Knowledge Related to Physics Concepts Held by Senior Citizens in An Exploration of Indigenous Knowledge Related to Physics Concepts Held by Senior Citizens in Chókwé, Mozambique. 0693(February). https://doi.org/10.1080/09500693.2015.1115137

Bayir, E., Cakici, Y., \& Ertas, O. (2013). Exploring Natural and Social Scientists ' Views of Nature of
Science Exploring Natural and Social Scientists ' Views of Nature of Science. International Journal of Science Education. 36(8), 37-41. https://doi.org/10.1080/09500693.2013.860496

Bell, R. L., \& Lederman, N. G. (2003). Understandings of the Nature of Science and Decision Making on Science and Technology Based Issues. Science Education, 87(3), 352-377. https://doi.org/10.1002/sce.10063

Bullen, J., \& Roberts, L. (2019). Driving Transformative Learning within Australian Indigenous Studies. The Australian Journal of Indigenous Education, 48(1), 12-23. https://doi.org/10.1017/jie.2017.40

Chaudhuri, B. (2016). Science in society: challenges and opportunities for indigenous knowledge in the presentday context. Global Bioethics, 26(2), 78-85, https:// doi.org/10.1080/11287462.2015.1037140

Dagher, Z. R., \& Erduran, S. (2016). Reconceptualizing the Nature of Science for Science. Science $\mathcal{E}$ Education. $\quad$ https://doi.org/10.1007/s11191-0159800-8

Dihamri, D. (2016). Kearifan Lokal Suku Serawai Di Kabupaten Bengkulu Selatan. Jurnal Georafflesia: Artikel Ilmiah Pendidikan Geografi, 1(2), 82-92. Retrieved

from: https://journals.unihaz.ac.id/index.php/g eorafflesia/article/view/151

Fasasi, R. A. (2017). Effects of ethnoscience instruction, school location, and parental educational status on learner' attitude towards science. International Journal of Science Education, 39(5), 548-564. https://doi.org/10.1080/09500693.2017.1296599

Iskandar, J. (2016). Etnobiologi dan Keragaman Budaya di Indonesia. Umbara: Indonesian Journal of Anthropology. $\quad 1(1)$. 27-42. https://doi.org/10.24198/umbara.v1i1.9602

Kampourakis, K. (2016). Position Paper The "General Aspects "Conceptualization as a Pragmatic and Effective Means to Introducing Students to Nature of Science. Journal of Research in Science Teaching (J RES SCI TEACH), 53(5), 667-682. https://doi.org/10.1002/tea.21305

Kaya, E., \& Erduran, S. (2016). From FRA to RFN : How the Family Resemblance Approach Can Be Transformed for Science Curriculum Analysis on Nature of Science. Science $\mathcal{E}$ Education. https://doi.org/10.1007/s11191-016-9861-3

Kaya, S., Erduran, S., Birdthistle, N., \& McCormack, O. (2018). Looking at the Social Aspects of Nature of Science in Science Education Through a New Lens: The Role of Economics and Entrepreneurship. Science and Education, 27(5-6), 457-478. https://doi.org/10.1007/s11191-018$\underline{9990-\mathrm{y}}$ 
Lederman, N. G., Abd-El-Khalick, F., Bell, R. L., \& Schwartz, R. S. (2002). Views of Nature of Science Questionnaire: Toward Valid and Meaningful Assessment of Learners' Conceptions of Nature of Science. Journal of Research in Science Teaching, 39(6), 497-521. https://doi.org/10.1002/tea.10034

Mccomas, W. F., \& Nouri, N. (2016). The Nature of Science and the Next Generation Science Standards: Analysis and Critique Standards: Analysis and Critique. Journal of Science Teacher Education, 27(5), 555-576. https://doi.org/10.1007/s10972-016-9474-3

Nola, R. (2011). A Family Resemblance Approach to the Nature of Science for Science Education. Sci \& Educ. 20, https://doi.org/10.1007/s11191-010-9293-4

Olson, J. K. (2018). The Inclusion of the Nature of Science in Nine Recent International Science Education Standards Documents. Science and Education, 27(7-8), 637-660. https://doi.org/10.1007/s11191-018-9993-8

Rist, S., \& Dahdouh-Guebas, F. (2006). Ethnosciences A step towards the integration of scientific and indigenous forms of knowledge in the management of natural resources for the future. Environment, Development and Sustainability, 8(4), 467-493. https://doi.org/10.1007/s10668-006$\underline{9050-7}$

Said-ador, N.K. (2017). Ethnochemistry of maguindanaons on the usage of household chemicals: Implications to chemistry education. Journal of Social Sciences (COESERJ-JSS), 6(2), 8-26. Retrieved from: https://ideas.repec.org/a/jso/coejss/v6y2017i2s p8-26.html

Temel, S., Şen, Ş., \& Özcan, Ö. (2018). The development of the nature of science view scale (NOSvs) at university level. Research in Science and Technological Education, 36(1), 55-68. https://doi.org/10.1080/02635143.2017.1338251

Triyadi, S., Sudradjat, I., \& Harapan, A. (2017). Kearifan Lokal Pada Bangunan Rumah Vernakular Di Bengkulu Dalam Merespon Gempa Studi Kasus: Rumah Vernakular di Desa Duku Ulu. Local Wisdom: Jurnal Ilmiah Kajian Kearifan Lokal, 2(1), 17. https://doi.org/10.26905/lw.v2i1.1366

Utami, S., Haneda, F., Silvikultur, D., Bogor, I. P., Akademik, J. L., \& Dramaga, K. I. P. B. (2010). Pemanfaatan Etnobotani dari Hutan Tropis Bengkulu sebagai Pestisida Nabati. Jurnal Manajemen Hutan Tropika. XVI(3), 143-147. https://doi.org/10.7226/itfm.16.3.\%25p

Wahono, B., \& Hariyadi, S. (2014). Pendidikan Karakter Yang Bersumber Dari Kearifan Lokal Masyarakat Suku Serawai Bengkulu Selatan. Jurnal Pembelajaran Biologi: Kajian Biologi dan
Pembelajarannya,

1(2), 169-174. https://doi.org/10.36706/fpbio.v1i2.4713 